\title{
Örgütsel Psikolojik Sermaye ve İş Tatmini İlişkisi: Bişkek'teki Yiyecek İçecek İşletmeleri Üzerine Bir Uygulama
}

\author{
Mehmet ULUTAȘ ${ }^{1}$
}

\section{$\ddot{\mathrm{O} z}$}

İsgörenlerin zayıf yönleri yerine güçlü yanlarına odaklanmalarının gerekliliğine işaret eden örgütsel psikolojik sermaye, iş tatmininde artışa neden olarak örgütlerde pozitif bir iklimin oluşmasına katkı sağlamaktadır. Araştırmada, örgütsel psikolojik sermaye ve iş tatmini ilişkisi incelenmiştir. Araştırma ile örgütsel psikolojik sermaye literatürünün zenginleştirilmesi amaçlanmaktadır. Yapılan bu çalışmada örneklem olarak Kırgıistan'ın başkenti Bişkek'te faaliyet gösteren yiyecek içecek işletmeleri çalışanları seçilmiştir. Araş̧ırmada bir anket formu kullanılmıştr. Bulgular ve Tartışma: Araştırmada, hem açılklayıcı faktör analizi hem de doğrulayıcı faktör analizi yapılarak ölçeklerin yapısal geçerliliği ve güvenirliği test edilmiştir. Yapısal eşitlik modellemesi ile oluşturulan yol analizi sonucunda örgütsel psikolojik sermayenin iş tatmini üzerinde anlamlı ve pozitif bir etkiye sahip olduğu tespit edilmiştir. Örgütsel psikolojik sermayenin alt boyutlarına bakıldığında; a) "Psikolojik dayanıklılık ve öz-yeterlilik" alt boyutunun "iş tatmini”" üzerinde herhangi bir anlamlı etkiye sahip olmadığı, b) "İyimserlik ve umut" alt boyutunun ise "iş tatmini" üzerinde pozitif yönde anlamlı bir etkiye sahip olduğu tespit edilmiştir. Çalışma ile işgörenlerin örgütsel psikolojik sermaye ve iş tatmini algıları ölçülmüş; aralarındaki ilişki çalışmanın bulguları olarak ayııntılı bir biçimde ortaya konmuştur. Buna göre, örgütsel psikolojik sermaye algısının yüksek olduğu işletmelerde işgörenlerin iş tatmini yüksek olmaktadır. Rekabetin çok yüksek olduğu günümüzde işletmeler, işgörenlerinin psikolojik sermaye ve iş tatminlerini artırarak rekabet üstünlügü elde edebileceklerdir.

Anabtar Kelimeler: Örgütsel Psikolojik Sermaye, İş Tatmini, Kırgızistan

The Relationship between Organizational Psychological Capital and Job Satisfaction: An Application on Food and Beverage Businesses in Bishkek

\begin{abstract}
Organizational psychological capital, which indicates the need for employees to focus on their strengths rather than their weaknesses, leads to an increase in job satisfaction, contributing to the formation of a positive climate in organizations. In the study, the relationship between organizational psychological capital and job satisfaction was examined. The research aims to enrich the organizational psychological capital literature. As a sample of this study, employees of food and beverage enterprises operating in Bishkek, the capital of Kyrgyzstan, were selected. A questionnaire was used in the study. Conclusions and discussion: the structural validity and reliability of the scales were tested by performing both explanatory factor analysis and confirmatory factor analysis. As a result of the path analysis created by structural equality modeling, it was found that organizational psychological capital has a significant and positive effect on job satisfaction. Looking at the lower dimensions of organizational psychological capital; a) "resilience and self-sufficiency" child size "does not have any significant effect on job satisfaction, b) "optimism and hope" child size "it has been found that job satisfaction has a significant effect on positive. The study measured employees ' perceptions of organizational psychological capital and job satisfaction; the relationship between them was detailed as the findings of the study. Accordingly, job satisfaction of employees is high in enterprises where organizational psychological perception of capital is high. At a time when competition is very high, businesses will be able to achieve a competitive advantage by increasing the psychological capital and job satisfaction of their employees.
\end{abstract}

Key Words: Organizational psychological capital, Job satisfaction, Kyrgyzstan

\section{Atıf İçin / Please Cite As:}

Ulutaş, M. (2021). Örgütsel psikolojik sermaye ve iş tatmini ilişkisi: Bişkek'teki yiyecek içecek işletmeleri üzerine bir uygulama. Manas Sosyal Araştırmalar Dergisi, 10(1), 578-590.

Geliş Tarihi / Received Date: 12.07.2020

Kabul Tarihi / Accepted Date: 08.10.2020

\footnotetext{
${ }^{1}$ Doç. Dr. - Kırgızistan Türkiye Manas Üniversitesi Turizm ve Otelcilik Yüksekokulu - Niğde Ömer Halisdemir Üniversitesi Niğde Sosyal Bilimler Meslek Yüksekokulu,mehmet.ulutas@manas.edu.kg,mulutas@ohu.edu.tr 


\section{Giriş}

Psikolojik sermaye kavramı, pozitif duyguları bünyesinde barındıran pozitif örgütsel davranış alanının bir unsuru olarak ortaya çıkmaktadır (Erkmen ve Esen, 2013, s. 23). İnsanların zayıf olan yerine güçlü olan yönlerine odaklanmalarının gerektiğini ortaya koyan pozitif örgütsel davranış olgusu ile birlikte ortaya çıkan psikolojik sermaye, örgütlerinde pozitif bir iklim yaratmak isteyen yöneticilerin üzerine yatırım yapmak zorunda oldukları temel bir olgudur (Keleş, 2011, s. 349). Bu çerçevede çalışma ile örgütsel psikolojik sermaye olgusu alt boyutları ile ortaya konmuş ve işgörenlerin iş tatmini üzerindeki etkisi ayrıntılı bir biçimde incelenmiştir.

\section{Örgütsel Psikolojik Sermaye}

Örgütsel psikolojik sermaye, kişilerdeki pozitif ruhsal durum olarak tanımlanmakta ve dört bileşen ile karakterize edilmektedir; (1) kendine güven duyma ve zorlayıcı görevlerde başarılı olmak için gerekli çabayı gösterme (öz-yeterlilik-self-efficacy); (2) halihazırda başarılı olduğu ve gelecekte de başarılı olacağ1 konusunda pozitif tavır takınma (iyimserlik-optimism); (3) temel amaçlara ulaşma ve başarılı olabilmek için gerektiğinde değişebilen farklı hedeflere yönlenebilme azmi (umut-hope) (4) sorunlar ve güçlüklerle kuşatıldığında, başarıya ulaşma hedefini sürdürme (dayanıklılık-resiliency) (Luthans vd., 2007, s. 3). Örgütsel psikolojik sermaye literatürde dört boyut altında incelenmektedir:

Öz-yeterlilik (Self-efficacy-Confidence): Öz-yeterlilik, bireylerin belli bir misyonu gerçekleștirmek için ihtiyaç duyduğu tüm niteliklere sahip olduğuna ilişkin kendisine olan inancı olarak ifade edilebilir (Kutanis ve Oruç, 2014, s. 151). Öz yeterliliği yüksek olan kişiler, işlerini yaparken kendilerini zorlayabilecek görevleri seçerler ve görevlerini yerine getirirken yüz yüze geldikleri problemler karşısında kendilerine olan inançlarını yitirmezler (Çetin, 2011, s. 375). Öz-yeterliği yüksek olan bireyler, kendilerine verilen bir görevde başarılı olabilmek için, gerekiyorsa doğal çevrelerini de değiştirmek üzere harekete geçme yeteneğine sahip kişilerdir (Clapp-Smith vd., 2009, s. 230).

Umut (Hope): Umutlu bireyler hedeflerine ulaşamadıkları zaman, bu çabaları sırasında aldıkları geribildirimleri, stratejilerini geliştirmek için kullanırlar. Böylece amaçlarını gerçekleştirmelerinin önünde bulunan engelleri aşmak için alternatif ve yaratıcı yollar aramaya daha eğilimli ve enerjik olurlar. Sonuç itibariyle umut, yaratıclliğı besleyen bir olgudur (Rego vd., 2012, s. 431). Umut sahibi olan işgörenler, düşünce süreçlerinde bağımsız olma eğilimindedirler. Kendilerine verilen zenginleştirilmiş görevleri yerine getirmek suretiyle motive olan dahili bir kontrol odağına sahiptirler (Toor ve Ofori, 2010, s. 342).

İyimserlik (Optimism): İyimserlik olgusu, genel itibariyle, Seligman'in (1998) atıf teorisine (attribution theory) dayandırılmaktadır. Seligman iyimserliği, olumlu olaylara ilişkin içsel (internal), nispeten istikrarlı (relatively stable) ve genel atıflara (general attributions); olumsuz olaylar için ise dişsal (external), nispeten istikrarsız (relatively unstable) ve spesifik mazeretlere (specific excuses) yönelme olarak tanımlamaktadır (Norman vd., 2010, s. 381). İyimserler, kendilerini olumsuz yönde etkileyen hadiseleri yorumlarken, "bu benim hatam değil-dışsal", "sadece bir kez oldu-istikrarsız" ve "sadece bu olaya mahsusspesifik" biçiminde düşünürlerken; kötümserler tam da bunun zıddı fikirlere sahiptirler (Larson ve Luthans, 2006, s. 81).

Psikolojik Dayanıklılık (Resilience): Psikolojik dayanıklılı̆̆a sahip çalışanlar, hem örgütsel değişimlere iştirak eder hem de en zor koşullar altında dahi ortama uyum sağlama ve başarılı olma becerisine sahiptirler (Avey vd., 2008, s. 54-55).

Örgütsel psikolojik sermaye üzerine çok sayıda ampirik çalışma yapılmıştır. Çetin vd. (2013, s. 95) kamu çalşsanları üzerine yaptıkları çalışmada, örgütsel psikolojik sermayenin alt boyutlarından "öz yeterlilik" ve "umut" boyutlarının "tükenmişlik" alt boyutlarının tamamının açıkladığını; ayrıca, psikolojik dayanıklılık ve iyimserlik alt boyutlan ile duygusal tükenme arasında negatif yönlü ilişki bulunduğunu tespit etmişlerdir. Özer vd. (2013, s. 437), sağlık çalışanları üzerine yaptıkları bir çalışmada, destekleyici niteliğe sahip organizasyon ikliminin, "örgütsel psikolojik sermaye" ile "iş doyumu" arasındaki ilişkide düzenleyici bir etkiye sahip olduğunu tespit etmişlerdir.

Polatçı (2014, s. 115), Tokat’ta görev yapan polis memurları üzerine yaptı̆̆1 çalışmada, psikolojik sermayenin performans üzerinde önemli bir etkiye sahip olduğunu, ancak dayanıklılık alt boyutunun performans boyutlarının tamamının pozitif yönde etkilerken, ümit boyutunun yalnızca görev performansı ve genel performansı olumlu yönde etkilediğini tespit etmiştir. Kaya vd. (2014, s. 47), Şanlıurfa'da görev yapan öğretmenler üzerine yaptıkları çalışmada, öğretmenlerin orta düzeyde özyeterlik-umut ve iyimserlik 
sermayesine sahip olduklar1; daha düşük kıdeme sahip öğretmenlerin daha yüksek psikolojik sermaye düzeylerine sahip oldukları, eğitim düzeyi yükseldikçe, psikolojik sermaye düzeyinin arttı̆̆ı ve son olarak aylık daha çok kitap okuyan öğretmenlerini az okuyan ya da hiç okumayanlara göre anlamlı derecede daha yüksek "psikolojik sermayeye" sahip oldukları bulgularına ulaşmışlardır.

McMurray vd. (2010, s. 436), yaptıkları çalışmada, yöneticilerin dönüşümcü (transformasyonal) liderlik davranışlarının işgörenler tarafından algılanma dereceleri ile örgütsel iklim, işgören mutluluğu, örgütsel bağllık ve psikolojik sermaye arasında güçlü pozitif ilişkiler olduğunu ortaya koymuşlardır. Gooty vd.'nin (2009, s. 353) yaptıkları ampirik çalışmadaki yapısal eşitlik modellemesinin sonuçları, liderin takipçilerinin "dönüşümcü liderlik" algıları ile "pozitif psikolojik sermaye" arasında bir ilişki bulunduğu ve buna ilave olarak "pozitif psikolojik sermaye" ile takipçilerin performansları arasında da bir ilişki bulunduğu varsayımını desteklemektedir.

Clapp-Smith vd.'nin (2009, s. 227) bir perakende giyim mağazalar1 zincirinden elde ettikleri verilerin sonuçları, yönetime duyulan güvenin psikolojik sermaye ile performans arasındaki ilişkiye aracılık ettiği ve otantik liderlik ile performans arasındaki ilisskiye kısmen aracıllk ettiğini göstermiştir. Toor ve Ofori (2010, s. 341), Singapur inşaat sektörü üzerine gerçekleştirdikleri araştırmada, psikolojik sermayenin, otantiklik ve dönüşümcü liderlik ile önemli ölçüde ilişkili olduğunu tespit etmişlerdir.

\section{İş Tatmini}

Emeğini ortaya koyarak örgütsel faaliyetlere katk1 sağlayan işgörenler, çalısma hayatları süresince, işleri, işyerleri, işverenleri ile ilgili çok çeşitli deneyimler yaşamaktadırlar. Kimi zaman sevinçli kimi zaman üzüntülü geçirilen bütün anlar, yaşanmışlıklar, paylaşımlar, sahip olunan bilgiler, hissedilen duygular, işgörenin örgütüne karşı bir tutum geliştirmesine sebep olmaktadır. İş tatmini, geliştirilen bu duygu ve tutumun olumlu bir sonucu olarak, işgörenin bedensel ve ruhsal olarak iyi bir durumda olması olarak tanımlanmaktadır (Oshagbemi, 2000, s. 88; Sevimli ve İşcan, 2005, s. 56). Literatürde 1920'li ylllarda ilk kez zikredilen iş tatmini, işgörenlerin çalışma koşullarından memnuniyeti ve sonuç olarak doyuma ulaşmalarıdır (Eğinli, 2009, s. 36). İş tatmini, genel itibariyle ihtiyaçların karşılanması ile ilişkilendirilir. Yaşamlarının hatırı sayllı bir bölümünü geçirdikleri işyerleri, işgörenlerin hem iş tatminleri hem de yaşam doyumları üzerinde önemli bir etkiye sahiptir (Avşaroğlu vd., 2005, s. 117). Bu noktada, yöneticilerin işgörenlerinin iş tatminleri ile ilişkili hususları tespit etmeleri, işletme faaliyetlerini icra ederken söz konusu tatmin faktörlerini göz önünde bulundurmaları, olumlu bir örgütsel iklim oluşturulması açısından büyük önem arz etmektedir (Kaya, 2010, s. 221).

\section{Örgütsel Bağlılık İş Tatmini İlişkisi}

Akçay (2012, s. 123), makine imalat sektörünün köklü kuruluşlarından kabul edilen bir işletme çalışanları üzerine yaptı̆̆ çalışmada, "psikolojik sermaye" ve alt boyutları ile "iş tatmini”" arasında pozitif ve anlamlı bir ilişki bulunduğu sonucuna ulaşmıştır. Çetin ve Basım (2011, s. 79), bankacılık sektörü üzerine yaptıkları çalışmada, "psikolojik sermaye"nin bir alt boyutu olan psikolojik dayanıklılık faktörünün "iş tatmini” ve "örgütsel bağlllık" ile ilişkili olduğunu tespit etmişlerdir.

Erkuş ve Fındıklı (2013, s. 302), çeşitli sektörlerde faaliyet gösteren firma çalışanları üzerine yaptıkları çalışmanın bulguları şu şekildedir; "psikolojik sermaye" ile "iş tatmini" ve "iş performansı" arasında pozitif, psikolojik sermaye ile "işten ayrılma niyeti" arasında negatif ilişki vardır. Faktörler alt boyutlar açısından ele alındığında ise, "umut" alt boyutu ile "iş tatminil" arasında pozitif, "işten ayrılma niyeti" arasında negatif; "dayanıklıllk" faktörü ile "iş tatmini" ve "iş performansı" arasında pozitif ilişki söz konusudur. Ayrıca, yüksek öz-yeterliliğe sahip işgörenlerin iş performansı da daha yüksek olmaktadır.

Ocak vd. (2016, s. 113) Boşnak öğretmenler üzerine yaptıkları ampirik çalşmada, "iyimserlik” alt boyutunun "iş tatmini”" ve "örgütsel bağlllık" üzerinde pozitif etkilerinin bulunduğunu tespit etmişlerdir. Biçkes vd. (2014, s. 97), yaptıkları ampirik çalışmada, "psikolojik sermaye"nin tüm boyutları ile "iş tatmini" arasında anlamlı ve pozitif yönlü ilişsi tespit etmiş; ayrıca duygusal emeğin alt boyutlarından doğal duyguların sergilenmesi ile iş tatmini ilişkisinde psikolojik sermayenin kısmi aracılık rolüne sahip olduğunu da ortaya koymuşlardır.

Çakmak ve Arabacı (2017, s. 890), Diyarbakır'da görev yapan öğretmenler üzerine yaptıkları çalışmada, psikolojik sermayenin, iş tatmini ve örgütsel bağlllık üzerinde olumlu etkiye sahip olduğunu ve iş tatmininin psikolojik sermaye ile örgütsel bağlllık arasında aracillk etkisine de sahip olduğunu tespit etmişlerdir. Çetin ve Varoğlu (2015, s. 105), Ankara'da faaliyet gösteren bir özel sektör firması çalışanları 
üzerine yaptıkları çalışmada, "psikolojik sermayenin" "işten ayrılma eğilimil”ni azalttığı, "performans”"1 ve "iş doyumu"nu artırdığını tespit etmişlerdir.

Luthans vd. (2008, s. 233), ABD'de sigorta vb. hizmet sektörü işletmeler ve ileri teknoloji şirketleri çalışanları üzerine yaptıkları ampirik çalışmada, "psikolojik sermaye" ile "iş tatmini" arasındaki anlamlı bir ilişki olduğunu ortaya koymuşlardır. Çetin (2011, s. 373) Ankara'da kamu personeli üzerine yaptı̆̆1 çalışmada, iş tatmininin "örgütsel psikolojik sermaye"nin, "esneklik", "umut" ve "iyimserlik" boyutları ile pozitif yönde ilişkili olduğunu tespit etmiştir. Larson ve Luthans'in (2006, s. 75) imalat işletmeleri üzerine yaptıkları çalışmanın bulguları, "psikolojik sermaye" ile "iş tatmini” ve "örgütsel bağlllık" arasında anlamlı bir ilişki olduğunu göstermektedir.

Literatür ve ampirik araştırma sonuçları dikkate alınarak, "örgütsel psikolojik sermaye" ve "iş tatmini" ilişkisini test etmek için aşağıdaki hipotezler geliştirilmiştir;

$\mathbf{H}_{1}$ : "Örgütsel psikolojik sermayenin iş tatmini üzerinde pozitif bir etkisi vardır."

$\mathbf{H}_{1 \mathrm{a}}$ : "Psikolojik dayanıklılığın iş tatmini üzerinde pozitif bir etkisi vardır."

$\mathbf{H}_{1 \mathrm{~b}}$ : "Öz-yeterliliğin iş tatmini üzerinde pozitif bir etkisi vardır."

$\mathbf{H}_{1 \mathrm{c}}$ : "İyimserliğin iş tatmini üzerinde pozitif bir etkisi vardır."

$\mathbf{H}_{1 \mathrm{~d}}$ : "Umutun iş tatmini üzerinde pozitif bir etkisi vardır."

Araştırma için öngörülen model Şekil 1' de gösterilmiştir.

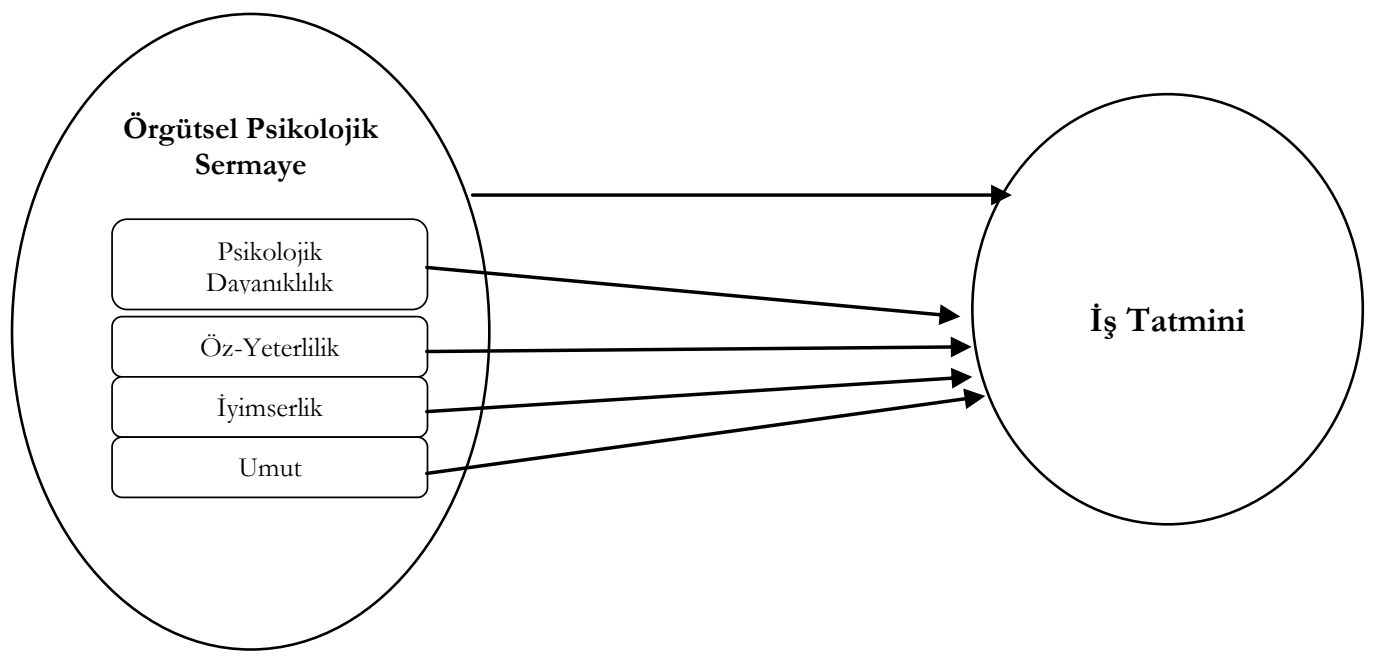

Şekil 1. Arasțtrma Modeli

Yöntem

Örgütsel psikolojik sermaye ve iş tatmini ilişkisinin belirlenmesini amaçlayan bu araştırmada, ilk olarak örneklem ve ölçeklere dair bilgilere yer verilmiş; akabinde örneklem vasitasılyla elde edilen veri kullanılarak geliştirilen modelin analizleri yapılmıştır. Değişkenler için önce "açıklayıcı faktör analizi" ve arkasından "doğrulayıcı faktör analizi" yapılmış ve daha sonra "yapısal eşitlik modeli" kullanılarak "yol analizi" yapılmıştır. Analizler neticesinde elde edilen bulgular literatürdeki bulgularla kıyaslanmak suretiyle işletme yönetimlerine ve diğer araştırmacılara birtakım önerilerde bulunulmuştur.

\section{Evren - Örneklem}

Kırgızistan'ın başkenti Bişkek'te faaliyet gösteren yiyecek içecek işletmelerinin çalışanları araştırmanın evrenini oluşturmaktadır. Araştırmanın örneklemini ise söz konusu çalışanların içerisinden tesadüfi olmayan örnekleme yöntemlerinden kolayda örnekleme yöntemiyle belirlenmiş olan denekler oluşturmaktadır. Bu çerçevede, kolayda örnekleme yöntemiyle seçilen toplam 150 katılımcıya araştırma için geliştirilmiş olan anketler basılı olarak dağıtılmıştır. Dağıtılan anket formlarından 145'inin doldurulmuş olarak teslim alınmıştır. Ancak, dolu anket formlarından 12'sinin de gelişigüzel bir şekilde doldurulduğu 
tespit edilmiş olup, bu anket formları analizlere dâhil edilmemiştir. Sonuç olarak, araştırmada kullanılan anket formlarının sayısı 133 ’te kalmıştır.

Tablo 1. Anket Yapılan Issletmeler Tablosu

\begin{tabular}{cccc}
\hline \multicolumn{3}{c}{ İsletmeler } \\
\hline 1 & Bishkek Jannat Resort (Mutfak) & 3 & Bishkek Park Funcity (Mutfak) \\
2 & Bishkek Sheraton Otel (Mutfak) & 4 & Bishkek Park Navat Kafe \\
\hline
\end{tabular}

Tablo 1'de listelenen Bişkek yiyecek içecek işletmelerine araştırmacı tarafindan bırak-topla yöntemi kullanılarak anketler verilmiş ve veriler toplanmıştır. Buna göre, araştırmaya katılanların demografik bilgileri aşă̆ıdaki gibidir;

Araştırmaya, 69’u erkek (\% 51,9), 64'ü kadın (\% 48,1) olmak üzere toplam 133 kişi katılmıştır. Araştırmaya katılanlar; yaş durumlarına göre \% 63,2'si (84 kişi) 18-35, \% 36,1’i (48 kişi) 36-50 yaş arası, yalnızca \% 0,8’i (1 kişi) 50 yaş üstü grupta bulunmaktadır. Araştırmaya katılanların \% 69,2'si (92 kişi) bekâr, \% 30,8’i (41 kişi) evlidir. Eğitim durumlarına göre, ankete katılanlar arasında en yüksek oran \% 69,9 (93 kişi) ile üniversite mezunlarına aittir. Üniversite mezunlarını \% 22,6 (30 kişi) ile lise mezunları takip etmektedir. Katılımcıların yalnızca \% 7,5'i (10 kişi) ise ilkokul mezunudur. Katılımcıların \% 60,9’u (81 kişi) mavi yaka çalışanlardan; \% 29,3’ü (39 kişi) beyaz yaka çalışanlardan oluşmakta; \% 9,8'i (13 kişi) ise yönetici grubunu temsil etmektedir. Katılımcıların \% 59,4’ü (79 kişi) 1 yıldan az; \% 33,8’i (45 kişi) 1-6 yıl arası; \% 6,8’i (9 kişi) ise 6 yıldan fazla süredir kurumlarında görevini sürdürmektedir

\section{Veri Toplama Araçları}

Araştırmada "veri toplama aracı" olarak anket yöntemi kullanılmıştır. Anket formu üç bölümden ve toplam 35 sorudan oluşmaktadır. Birinci bölümde 6 sorudan oluşan demografik faktörlere ait sorular, ikinci bölümde 24 sorudan oluşan "örgütsel psikolojik sermaye" ölçeği (4 boyut), üçüncü bölümde ise 5 maddeden oluşan "iş tatmini”" ölçeği (tek boyut) yer almaktadır.

“Örgütsel Psikolojik Sermaye” Ölçeği. Araştırmada "örgütsel psikolojik sermaye”, Luthans vd. (2007) tarafından geliştirilmiş ve Çetin ve Basım (2012) tarafından Türkçeye uyarlanmış ve güvenirlik ve geçerlilik testleri yapılmış olan "örgütsel psikolojik sermaye" ölçeği ile ölçümlenmiştir. Ölçek orijinal biçimiyle 24 soru ve 4 boyut üzerinden yapılandırılmıştır. Boyutlar, "iyimserlik (optimism)", "umut (hope)", "öz-yeterlilik (efficacy)" ve "psikolojik dayanıklılık (resilience)" olarak adlandırılmışlardır. Boyutların her biri 6'lar soru ile ölçümlenmiştir. Anket sorularına verilen cevaplar, 5'li Likert tipi "1: Kesinlikle Katılmiyorum; 2: Katılmiyorum; 3: Ne Katıliyorum Ne Katılmiyorum; 4: Katıllyorum; 5: Kesinlikle Katıliyorum” ölçek vasıtasıyla alınmıştır. Çetin ve Basım (2012, s. 129) ölçeğin alt boyutlarından "iyimserlik" için 0,67, "umut" için 0,81 , "psikolojik dayanıkl1l1k" için 0,68 ve "öz yeterlilik" için ise 0,85 Cronbach Alfa katsayısına ulaşmış ve ölçeğin toplamı için Cronbach Alfa katsayısını 0,91 olarak hesaplamışlardır. "Örgütsel psikolojik sermaye" ölçeğinin yapı geçerliliğini test etmek için önce açılayıcı faktör analizi yapilmıştır.

Tablo 1. "Örgütsel Psikolojik Sermaye Ölçeği Faktör Analizi Sonuclarn"

\begin{tabular}{|c|c|c|}
\hline Sorular & Eş Kökenlilik & Faktör Yükü \\
\hline \multicolumn{3}{|c|}{$\begin{array}{c}\text { Psikolojik Dayanıklılık ve Öz Yeterlilik Faktörü } \\
\text { ( Özdeğer: 4,594; Açıklanan Varyans\%: 41,761; Ortalama: 4,0163; Güvenirlik: ,801) }\end{array}$} \\
\hline "Genellikle, işimdeki stresli şeyleri sakin bir şekilde hallederim." & ,646 & ,804 \\
\hline "Daha önceleri zorluklar yaşadığım için, işimdeki zor zamanların üstesinden gelebilirim." &, 562 &, 732 \\
\hline "Çalışma alanımda, hedefler/amaçlar belirlemede kendime güvenirim." &, 585 &, 723 \\
\hline "Bir grup iş arkadaşıma bir bilgi sunarken kendime güvenirim." &, 534 & 660 \\
\hline "Organizasyonun stratejisi konusundaki tartışmalara katkıda bulunmada kendime güvenirim." & 439 & 632 \\
\hline "İşimde birçok şeyleri halledebileceğimi hissediyorum." & 358 & 440 \\
\hline
\end{tabular}

İyimserlik ve Umut Faktörü

(Özdeğer: 1,469; Açıklanan Varyans \%: 13,352; Ortalama: 3,9910; Güvenirlik: ,799)

\begin{tabular}{llr}
\hline "İşime "her şeyde bir hayır vardır" şeklinde yaklaşıyorum." &, 786 &, 886 \\
"İşimle ilgili gelecekte başıma ne geleceği konusunda iyimserimdir." &, 735 &, 795 \\
"Şu anda iş amaçlarımı sıkı bir şekilde takip ediyorum.” &, 526 &, 693 \\
"Mevcut iş amaçlarıma ulaşmak için birçok yol düşünebilirim." &, 602 &, 587 \\
"İşimle ilgili gelecekte başıma ne geleceği konusunda iyimserimdir." &, 290 &, 517 \\
\hline
\end{tabular}

"Faktör çıkarma metodu: Temel bileşenler analizi; Döndürme metodu: Varimax; Kaiser-Meyer-Olkin Örneklem Yeterliliği: \%80,5; Bartlett’s Küresellik Testi için Ki- Kare: 584,720; df: 55; p<0,01” 
Örgütsel psikolojik sermaye ölçeğinin orijinal biçiminde "iyimserlik", "umut”, “öz-yeterlilik", "psikolojik dayanıklılık" olmak üzere dört faktör bulunmaktaydı. Ancak yapılan faktör analizinde, faktör yükleri uygun bileşenlere dağılmayan çok sayıda ifade olduğu görülmüş ve uygun bileşenlere dağılmayan "Bu is yerinde, ișler asla benim istediğim şekilde yürümez", "Bu aralar kendim için belirlediğim iș amaçlarmm yerine

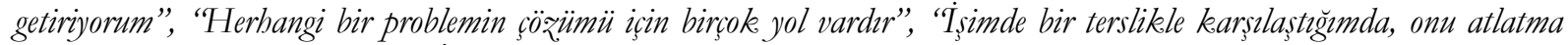
konusunda sıkint yaşzorum", "İşimde benim için belirsiz̨likler olduğunda, her zaman en iyisini isterim", "Eğer zorunda kalirsam, ișimde kendi başıma yeterim", "Eğer ișimde bir şeyler benim için yanlş gidecekse, o şekilde gider", "Eğer

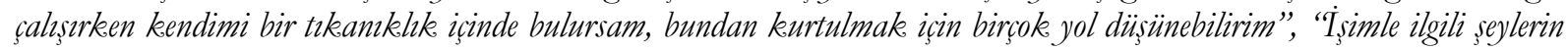

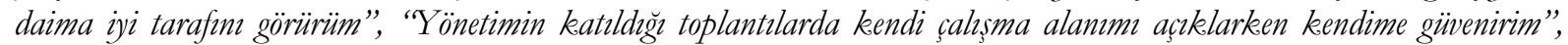
"Usun dönemli bir probleme çözüm bulmaya çalşsırken kendime güvenirim", "Şu anda, işimde kendimi çok başarnh olarak görüyorum", İsimdeki zorluklarn genellikle bir șekilde hallederim", "Organizasyon dişındaki kişilerle (tedarikçiler, tüketiciler vb.) problemleri tartışmak için temas kurarken kendime güvenirim" ifadeleri ölçekten çıkarılmışır. Ancak buna rağmen, orijinalinde dört faktör olarak yer alan ölçek, yapılan analizde iki faktörlü bir dağılım sergilemiştir. "Psikolojik dayanıklılık" ve "öz-yeterlilik" alt boyutlan tek faktör altında yer alırken; "iyimserlik" ve "umut" alt boyutları da tek faktör altında birleşmiştir. İfadeler gözden geçirildiğinde, dayanıklılık ve öz-yeterlilik boyutların birbirine çok yakın olduğu ve yine "iyimserlik" ve "umut" alt boyutlarının da birbirine çok yakın olduğu anlaşılmaktadır. Bu çerçevede örgütsel psikolojik sermaye değişkeninin çalışmada iki alt boyutlu olarak dikkate alınmasına karar verilmiş ve hipotezler de buna uygun olarak iki alt hipotez olarak revize edilmiştir.

Sonuç itibariyle, "psikolojik dayanıkll1k" ve "Öz-yeterlilik" faktörünün “öz değeri” 4,594'dür ve toplam "varyans"ın \%41,761'ini açıklamaktadır. Faktörün "güvenirliğì" 0,801 olarak tespit edilmiştir. "İyimserlik" ve "umut" faktörünün öz değeri 1,468'dur ve toplam "varyans" 1 \% \%13,352'sini açıklamaktadır. Faktörün "güvenirliğı" 0,799 olarak tespit edilmiştir.

Ölçeğin "Bartlett Testi” için ki-kare 584,729 ve "p anlamllık değeri” 0,01'den küçük olarak gerçekleşmiştir. "Kaiser-Meyer-Olkin" örneklem değeri 0,805 'dir. Test sonucu elde edilen değerler, verilerin "faktör analizi" için uygun olduğunu göstermektedir.

Açıklayıcı faktör analizinden sonra AMOS paket programı yardımıyla Şekil 2'de görüleceği üzere "doğrulayıcı faktör analizi” yapılmıştır.

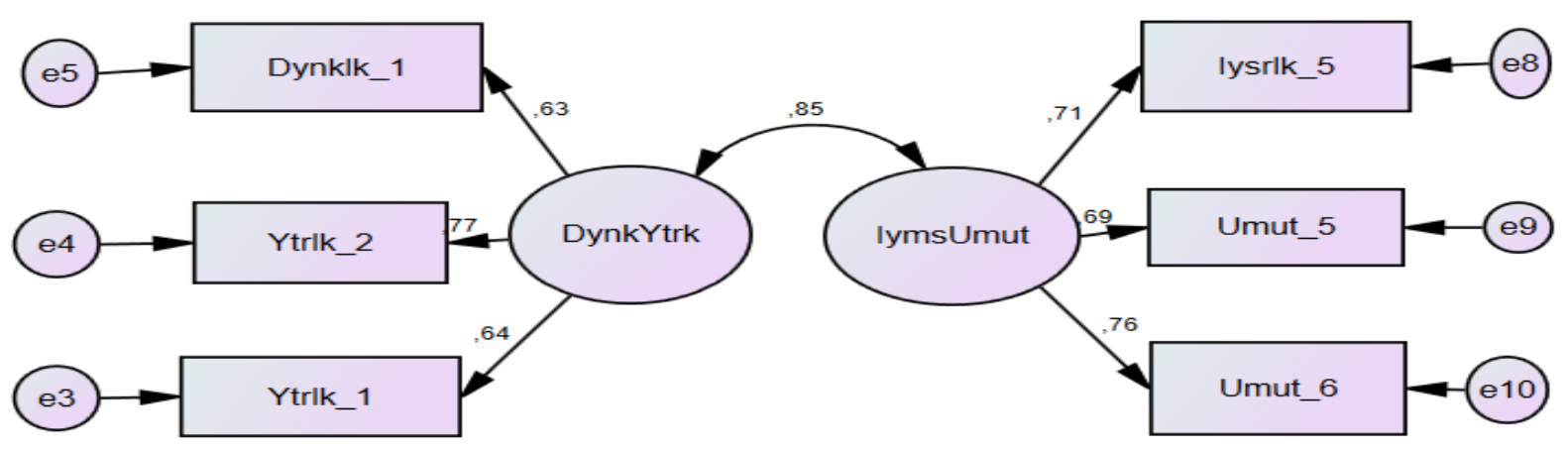

Şekil 2. Örgütsel Psikolojik Sermayenin Ölçeğinin Doğrulayıcı Faktör Analiæi Sonuclar

Doğrulayıcı faktör analizinde, estimates değerleri 0,60 'ın altında olan "Genellikle, işimdeki stresli şeyleri sakin bir şekilde hallederim", "Organizasyonun stratejisi konusundaki tartışmalara katkıda bulunmada kendime güvenirim", "İşimde birçok şeyleri halledebileceğimi hissediyorum”, "İşime "her şeyde bir hayır vardır" şeklinde yaklaşıyorum", "İşimle ilgili gelecekte başıma ne geleceği konusunda iyimserimdir" ifadeleri de ölçekten çıkarılmıstır.

Ölçeğe ait uyum iyiliği değerleri Tablo 3'de gösterilmiştir;

Tablo 2. Örgütsel Psikolojik Sermaye Ölçeğinin Uyum İyiliği Değerleri

\begin{tabular}{lccccccccc}
\hline \multirow{2}{*}{ Değişkenler } & & & CMIN/ & GFI & AGFI & CFI & NFI & TLI & RMSEA \\
& $\mathbf{X}^{\mathbf{2}}$ & df & DF $\leq 5$ & $\geq .85$ & $\geq .80$ & $\geq .90$ & $\geq .90$ & $\geq .90$ & $\leq .08$ \\
\hline Örgütsel PsikolojikSermaye & 15,5 & 8 & 1,95 & 0,96 & 0,90 & 0,96 & 0,94 & 0,94 & 0,08 \\
\hline
\end{tabular}


ULUTAŞ

Örgütsel Psikolojik Sermaye ve İş Tatmini İlişkisi: Bişkek'teki Yiyecek İ̧̧ecek İşletmeleri Üzerine Bir Uygulama

Tablo 3'de görüleceği üzere örgütsel psikolojik sermaye ölçeğinin uyum iyiliği değerleri, kabul edilebilir aralıklar içerisinde yer almaktadır. Ölçeğin güvenirlik değerleri için yapılan analiz sonucunda elde edilen Cronbach Alpha katsayıları Tablo 4'deki gibidir;

Tablo 3. Örgütsel Psikolojik Sermaye Ölçeğinin Güvenirlik Analiæ̦i Sonuclar

\begin{tabular}{llcc}
\hline & \multicolumn{1}{c}{ Faktörler } & Cronbach Alpha & Soru Sayıs \\
\hline $\mathbf{1}$ & Psikolojik Dayanıklılık ve Öz Yeterlilik & 0,713 & 3 \\
$\mathbf{2}$ & İyimserlik ve Umut & 0,765 & 3 \\
\hline
\end{tabular}

İş Tatmini Ölçeği. Araştırmada kullanılan iş tatmini (job satisfaction) ölçeği, Hackman ve Oldham (1975) tarafindan geliştirilmiş ve Şeşen (2010) tarafindan Türkçeye çevrilmiş ve güvenirlik ve geçerlik testleri yapılmışıtır. Ölçek, tek boyut ve 5 ifadeden oluşmaktadır. Anket sorularına verilen cevaplar, 5'li Likert tipi "1: Kesinlikle Katılmıyorum; 2: Katılmıyorum; 3: Ne Katllyorum Ne Katılmiyorum; 4: Katıllyorum; 5: Kesinlikle Katıllyorum" ölçek vasıtasıyla alınmıştır. Şeşen (2010, s. 198), ölçeğin "güvenirlik" katsayısını 0,84 olarak tespit etmiştir. "İş tatmini” ölçeğinin yap1 geçerliliğini test etmek amacıyla önce açılayıcı faktör analizi yapılmış ve analiz sonucunda verilerin ölçeğin "tek faktörlü" yapısına uyum sağladığı tespit edilmiştir. "İş tatmini” ölçeğinin “faktör analizi” sonuçları Tablo 5’te verilmiştir;

Tablo 4. "İs Tatmini Ölçeğine Ait Açıklayııı Faktör Analiz̨i Sonucları"

\begin{tabular}{|c|c|c|}
\hline “Sorular" & $\begin{array}{c}\text { "Eş } \\
\text { Kökenlilik" }\end{array}$ & $\begin{array}{l}\text { "Faktör } \\
\text { Yükü" }\end{array}$ \\
\hline \multicolumn{3}{|c|}{ İş Tatmini Faktörü - ( Özdeğer: 5,361; Açılklanan Varyans \%: 28,214; Ortalama: 2,5152; Güvenirlik: ,814) } \\
\hline "İşimden çok keyif alıyorum." & 784 & $\overline{885}$ \\
\hline "İşimde, diğer birçok insandan daha mutlu olduğumu düşünüyorum." & ,772 & 879 \\
\hline "Genel olarak işim beni tatmin ediyor." & 646 & 804 \\
\hline "Mevcut isimin, bulabileceğim diğer islerden dah & 538 & .734 \\
\hline "İşim benim için bir hobi gibidir." & ,421 & 648 \\
\hline
\end{tabular}

"Faktör çıkarma metodu: Temel bileşenler analizi; Döndürme metodu: Varimax; Kaiser-Meyer-Olkin Örneklem Yeterliliği: ,803; Bartlett's Küresellik Testi için Ki- Kare: 326,405; df: 10; p<0,01”

"İș tatmini” ölçeğine ilişkin olarak yapılan "açıklayıcı faktör analizi” sonucunda, faktör yüklerinin uygun biçimde tek bir faktöre yüklendiği görülmüsstür. Buna göre, "iş tatmini” faktörünün "öz değeri”" 5,361'dir ve toplam "varyans"ın \%28,214'ünü açıklamaktadır. Faktörün "güvenirliğg’” 0,814 olarak tespit edilmiştir.

Ölçeğin "Bartlett Testi" için ki-kare 326,405 ve "p anlamlllık değeri” 0,01'den küçük olarak gerçekleşmiştir. "Kaiser-Meyer-Olkin" örneklem değeri 0,803'dür. Test sonucu elde edilen değerler, verilerin "faktör analizi" için uygun olduğunu göstermektedir.

“İş tatmini” ölçeği için ayrıca AMOS paket programı ile "doğrulayıcı faktör analizi” de yapılmıştır. Doğrulayıcı faktör analizi sonucunda verilerin ölçeğin "tek faktörlü" yapısına uyum sağladığı tespit edilmiştir.

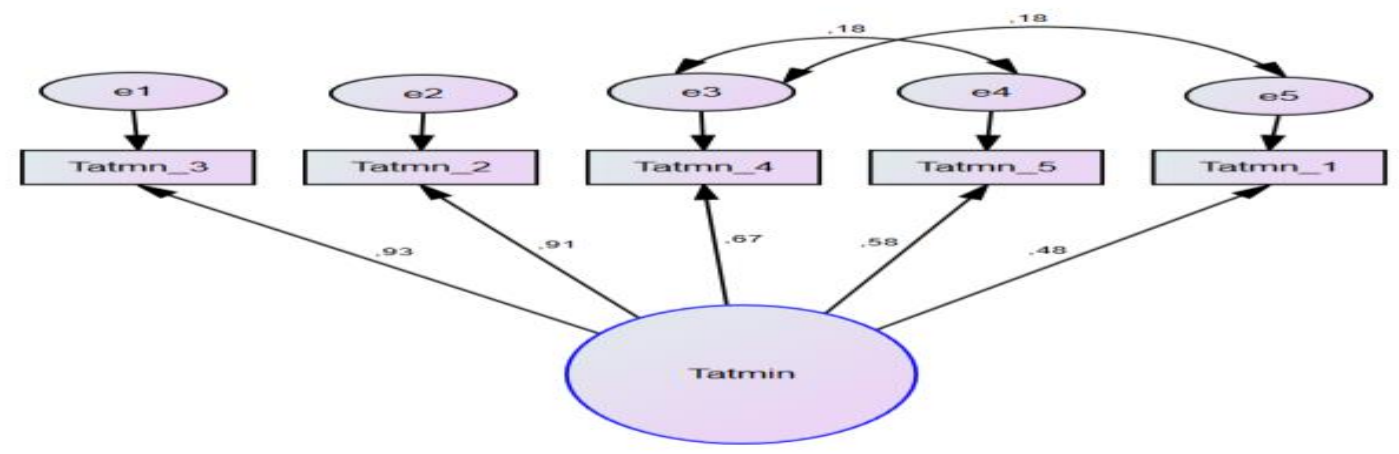

Şekil 3. İs Tatmini Ölçeğinin Doğrulayııı Faktör Analizi Sonuclar

Ölçeğin uyum iyiliği değerleri Tablo 6'da sunulmuştur; 
Tablo 5. İș Tatmini Ölçĕginin Uyum İyiliğ̀i Değerleri

\begin{tabular}{lccccccccc}
\hline "Değişkenler" & & & CMIN/ & GFI & AGFI & CFI & NFI & TLI & RMSEA \\
& $\mathrm{X}^{\mathbf{2}}$ & df & DF $\leq 5$ & $\geq .85$ & $\geq .80$ & $\geq .90$ & $\geq .90$ & $\geq .90$ & $\leq .08$ \\
\hline "İş Tatmini" & 3,6 & 3 & 1,2 & 0,98 & 0,94 & 0,99 & 0,98 & 0,99 & 0,04 \\
\hline
\end{tabular}

Tablo 6'da görüleceği üzere örgütsel psikolojik sermaye ölçeğinin uyum iyiliği değerleri, kabul edilebilir aralıklar içerisinde yer almaktadır.

Ölçeğin güvenirlik değerleri için yapılan analiz sonucunda elde edilen Cronbach Alpha katsayıları Tablo 7'deki gibidir;

Tablo 6. Iss Tatmini Ölçeğine Ait Cronbach Alpha Güvenirlik Katsaynları

\begin{tabular}{lccc}
\hline & Faktörler & Cronbach Alpha & Soru Sayıs1 \\
\hline 1 & İş Tatmini & 0,831 & 5 \\
\hline
\end{tabular}

Literatürde "psikolojik dayanıklıllk", “öz-yeterlilik", “iyimserlik” ve "umut” olmak üzere 4 alt boyut'ta incelenmiş olan örgütsel psikolojik sermaye değişkeni, yapılan açıklayıcı faktör analizinde ifadelerin dört yerine iki faktör altında toplanmaları sebebiyle iki alt boyut olarak incelenmiştir. Psikolojik dayanıklilık ve öz-yeterlilik tek faktör altında, iyimserlik ve umut da diğer bir faktör altında bir araya gelmiştir. Dikkat edilecek olursa, psikolojik dayanıklılık ve öz-yeterlilik boyut olarak birbiri içerisinde değerlendirmeye yakın olup; iyimserlik ve umut faktörleri de katılımcıların birbirine benzer algilar geliştirebileceği çok yakın faktörleri ifade etmektedir.

Sonuç olarak literatüre geliştirilmiş olan hipotezler, açıklayıcı faktör analizi sonuçları dikkate alınarak aşağıdaki şekilde yeniden düzenlenmiştir.

$\mathbf{H}_{1}$ : "Örgütsel psikolojik sermayenin iş tatmini üzerinde pozitif bir etkisi vardır."

$\mathbf{H}_{1 \mathrm{a}}$ : "Psikolojik dayanıklılık ve öz-yeterliliğin iş tatmini üzerinde pozitif bir etkisi vardır."

$\mathbf{H}_{\mathbf{1 b}}$ : "İyimserlik ve umutun iş tatmini üzerinde pozitif bir etkisi vardır."

\section{Verilerin Analizi}

Araştırmanın bu bölümünde, AMOS 23 paket programı vasıtasıyla yapısal eşitlik modeli kullanılarak oluşturulan "yol analizi”"nden elde edilen bulgulara ve bunlara ait yorumlara yer verilmiştir.

\section{Yol Analizi}

Değişkenler arasındaki ilişkiyi tespit etmek için yapılan yol analizinde, uyum iyiliği değerlerini kabul edilebilir seviyeye çıkarmak için, "Bir grup iş arkadaşıma bir bilgi sunarken kendime güvenirim", "Mevcut işimin, bulabileceğim diğer işlerden daha ilgi çekici olduğunu düşünüyorum", "İşim benim için bir hobi gibidir" ifadeleri de ölçekten çıkarılmıştır.

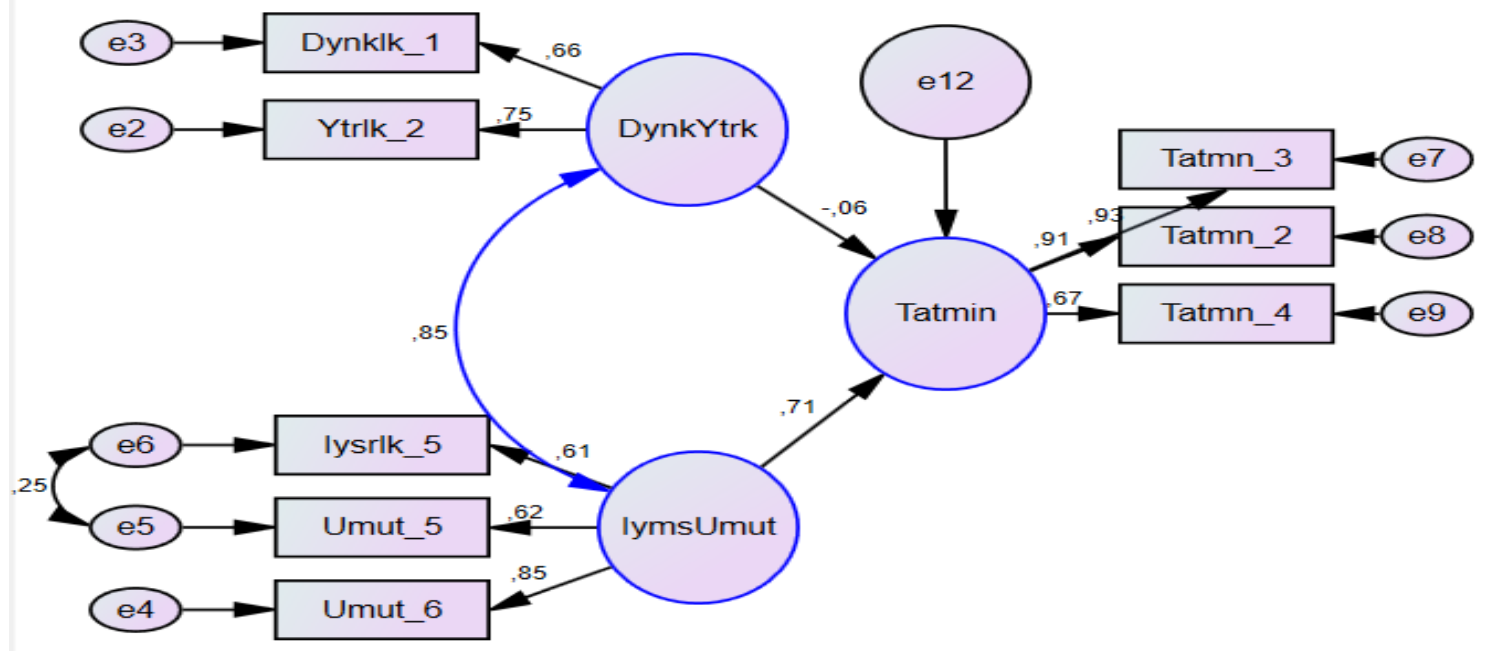

Şekil 4. Örgütsel Psikolojik Sermaye ve İs Tatmini Ilişkisine Ait Yol Analizi 
Yol analizi uyum iyiliği değerleri Tablo 8'de sunulmuştur.

Tablo 7. Yol Analiæi Uyum İyiliği Değerleri

\begin{tabular}{lcccccccccc}
\hline “Değişkenler" & $\mathbf{X}^{2}$ & df & $\begin{array}{c}\text { CMIN/ } \\
\text { DF } \leq 5\end{array}$ & $\begin{array}{c}\text { GFI } \\
\mathbf{2 . 8 5}\end{array}$ & $\begin{array}{c}\text { AGFI } \\
\mathbf{2 . 8 0}\end{array}$ & $\begin{array}{c}\text { CFI } \\
\mathbf{2 . 9 0}\end{array}$ & $\begin{array}{c}\text { NFI } \\
\mathbf{2 . 9 0}\end{array}$ & $\begin{array}{c}\text { TLI } \\
\mathbf{2 . 9 0}\end{array}$ & $\begin{array}{c}\text { IFI } \\
\mathbf{2 . 9 0}\end{array}$ & RMSEA $\leq . \mathbf{0 8}$ \\
\hline $\begin{array}{l}\text { "Örgütsel Psikolojik } \\
\text { Sermaye-İş Tatmini" }\end{array}$ & 24,7 & 16 & 1,54 & 0,96 & 0,91 & 0,98 & 0,95 & 0,96 & 0,98 & 0,06 \\
\hline
\end{tabular}

Tablo 8'de görüleceği üzere örgütsel psikolojik sermaye ölçeğinin uyum iyiliği değerleri, kabul edilebilir aralıklar içerisinde yer almaktadır.

Tablo 8, model'e ait uyum iyiliği değerlerini (Goodness of Fit Indices) göstermektedir. Modelin genel uyumunun belirlenmesi için başlangıç "uyum indeksi" olarak "ki-kare uyum iyiliği indeksi"ne (chi-square goodness of fit) bakılmaktadır. Ki-kare değerinin anlamlı bulunmaması ve $\mathbf{X}^{2} /$ sd (Amos'da CMIN/df şeklinde göstermektedir) değerinin bazı araştırmacılara göre 3'ten küçük ya da 3'e eşit, bazılarına göre ise 5’ten küçük ya da 5'e eşit olması, modelin uyumluluğunu ifade etmektedir (Karagöz, 2016, s. 969). Tablo incelendiğinde görüleceği üzere; $\mathbf{X}^{2} / \mathrm{df}$ değeri, 1,54 olup, literatürde $\mathbf{X}^{2} / \mathrm{df}$ değeri için kabul edilebilir değerler olan 3 ve 5 aralıklarının daha da altında olup kabul edilebilir düzeydedir.

Analizde ayrıca modelin karşılaştırmalı uyum indekslerine (comparative fit indices) de bakılmıştır. Karşılaştırmalı "uyum indeksleril"nden "NFI (Normlaştırılmış Uyum İndeksi-Normed Fix Index)" değerinin 0,90 ve üstü kabul edilebilir, 0,95 ve üstü ise iyi uyumu göstermektedir (Karagöz, 2016, s. 969). Model'de NFI değeri, 0,95 olarak tespit edilmiş olup modelin iyi uyuma sahip olduğunu kanıtlayan değerlerden birini oluşturmaktadır.

Karş1laştırmalı "uyum indeksleri”"nden "TLI (Tucker-Lewis Indeksi)" değerinin 0,90 ve üstü kabul edilebilir, 0,95 ve üstü ise iyi uyumu göstermektedir (Karagöz, 2016, s. 970). Model'de TLI değeri, 0,96 olarak tespit edilmiş olup modelin iyi uyuma sahip olduğunu kanıtlayan diğer bir uyum indeksinden birini oluşturmaktadır.

Karşılaştırmalı "uyum indeksleri"nden "IFI (Artırmalı Uyum İndeksi-Incremental Fit Index)" değerinin 0,90 ve üstü kabul edilebilir, 0,95 ve üstü ise iyi uyumu göstermektedir (Karagöz, 2016, s. 970). Model'de IFI değeri, 0,98 olarak tespit edilmiş olup modelin iyi uyuma sahip olduğunu kanıtlayan diğer bir uyum indeksinden birini oluşturmaktadır.

Karşılaştırmalı "uyum indeksleri"nden "CFI (Karşılaştırmalı Uyum İndeksi-Comperative Fit Index)" değerinin 0,95 ve üstü kabul edilebilir, 0,97 ve üstü ise iyi uyumu göstermektedir (Karagöz, 2016, s. 970). Model'de CFI değeri, 0,98 olarak tespit edilmiş olup modelin iyi uyuma sahip olduğunu kanıtlayan diğer bir uyum indeksinden birini oluşturmaktadır.

Karşılaştırmalı "uyum indeksleri”"nden "RMSEA (Yaklaşık Hataların Ortalama Karakökü-Root Mean Square Error of Approximation)" değerinin 0,08'e eşit ya da daha küçük olması halinde kabul edilebilir, 0,05’e eşit ya da daha küçük ise iyi uyumu göstermektedir (Karagöz, 2016, s. 971). Model'de RMSEA değeri, 0,06 olarak tespit edilmiş olup kabul edilebilir düzey içerisinde kalmaktadır.

Mutlak "uyum indeksleri" nden "GFI (İyilik Uyum İndeksi-Goodness of Fit Index") değerinin 0,85 ve üstü kabul edilebilir, 0,90 ve üstü ise iyi uyumu göstermektedir (Karagöz, 2016, s. 971). Model'de GFI değeri, 0,96 olarak tespit edilmiş olup modelin iyi uyuma sahip olduğunu göstermektedir.

Mutlak "uyum indeksleri”"nden “AGFI (Düzeltilmiş İyilik Uyum İndeksi-Adjuestment Goodness of Fit Index)" değerinin 0,85 ve üstü kabul edilebilir, 0,90 ve üstü ise iyi uyumu göstermektedir (Karagöz, 2016, s. 971). Model'de GFI değeri, 0,91 olarak tespit edilmiş olup modelin iyi uyuma sahip olduğunu göstermektedir.

\section{Bulgular}

Yapısal modelde esas itibariyle bir hipotez inceleme konusu yapılmış olup bu hipoteze ait iki adet alt hipotez de bulunmaktadır. Tablo 9'da gösterilen modelin sonuçları dikkate alındığında hipotezler ile ilgili olarak aşağıdaki sonuçlara ulaşılmışır; 
Tablo 8. Modelin Sonuçlar

\begin{tabular}{|c|c|c|c|c|c|c|c|}
\hline & & & $\beta 1$ & $\beta 2$ & S.E. & C.R. & $\mathbf{P}$ \\
\hline \multicolumn{8}{|c|}{ Ölçüm Modeli } \\
\hline Ytrlk_2 & $\begin{array}{l}<-- \\
\end{array}$ & DynkYtrk & 0,754 & 1,272 & 0,21 & 6,047 & $<0,001$ \\
\hline Dynklk_1 & $<---$ & DynkYtrk & 0,657 & 1 & & & \\
\hline Umut_6 & $<---$ & IymsUmut & 0,845 & 1 & & & \\
\hline Umut_5 & $<---$ & IymsUmut & 0,62 & 0,813 & 0,12 & 6,636 & $<0,001$ \\
\hline Iysrlk_5 & $<---$ & IymsUmut & 0,608 & 0,843 & 0,13 & 6,502 & $<0,001$ \\
\hline Tatmn_3 & $<---$ & Tatmin & 0,926 & 1 & & & \\
\hline Tatmn_2 & $<---$ & Tatmin & 0,913 & 0,985 & 0,07 & 14,46 & $<0,001$ \\
\hline Tatmn_4 & $<---$ & Tatmin & 0,674 & 0,652 & 0,07 & 9,144 & $<0,001$ \\
\hline \multicolumn{8}{|c|}{ YEM Yol Analizi } \\
\hline Tatmin & $<---$ & $\begin{array}{l}\text { Psikolojik Dayanıklılık ve } \\
\text { Öz-Yeterlilik }\end{array}$ & $-0,056$ & $-0,091$ & 0,5 & $-0,184$ & 0,854 \\
\hline Tatmin & $<---$ & İyimserlik ve Umut & 0,711 & 0,854 & 0,38 & 2,264 & 0,024 \\
\hline
\end{tabular}

$\beta 1$ : Standart Katsaylar, $\beta 2$ : Standart Olmayan Katsayılar

" $\mathrm{H}_{\mathbf{1}}$ : Örgütsel psikolojile sermayenin is tatmini üzerinde pozitif bir etkisi varder" hipotezi yol diyagramından elde edilen sonuçlara göre kabul edilmektedir

a. "Psikolojik dayanıkl1l1k" ve "öz-yeterlilik" ile "iş tatmini” arasındaki yol katsayısı istatistiksel olarak anlamlı bulunmamıştır $(\beta=-0,091, p=0,854)$. Bu sebeple, "H1a: Psikolojik dayanıkl1t1k ve özyeterliliğin iş tatmini üzerinde pozitif bir etkisi vardır" alt hipotezi, reddedilmektedir.

b. İyimserlik ve umut ile iş tatmini arasındaki yol katsayısı istatistiksel olarak anlamlı bulunmuştur $(\beta=0,854, p=0,024)$. "H1b: İyimserlik ve umut'un iş tatmini üzerinde pozitif bir etkisi vardır" alt hipotezi, kabul edilmektedir.

\section{Tartışma, Sonuç ve Öneriler}

Örgütlerin nasıl güçlü ve zayıf yanları varsa, bireylerin de güçlü yanları olduğu gibi birtakım zayıf yanları da bulunmaktadır. Bunlar, bireylerin avantajları ya da dezavantajları olarak da ifade edilebilir. Örgütsel psikolojik sermaye, temelde, işgörenlerin zayıf yanlarına değil güçlü yanlarına daha fazla odaklanmaları üzerinde durmaktadır. Böyle bir odaklanma hali, işgörenlerin iş tatminini artırmakta ve örgüt iklimi pozitif bir dönüşüm yaşamaktadır.

Bu çerçevede araștırma ile "örgütsel psikolojik sermaye" ve "iș tatmini”" arasındaki ilişki incelenmiştir. Böylece, "örgütsel psikolojik sermaye" ve "iş tatmini”"ne ilişkin literatürün zenginleştirilmesi amaçlanmıştır.

Araştırmanın örneklemini, Kırgızistan'ın başkenti Bişkek’te faaliyet gösteren yiyecek içecek işletmeleri çalışanları oluşturmuştur. Tamamı "5'li Likert tipi" ifadelerden oluşan, Luthans vd. (2007) tarafindan geliştirilmiş ve Çetin ve Basım (2012) tarafindan Türkçeye uyarlanmış ve "güvenirlik" ve "geçerlilik" testleri yapılmış örgütsel psikolojik sermaye ölçeği ile Hackman ve Oldham (1975) tarafından geliştirilmiş ve Şeşen (2010) tarafindan Türkçeye çevrilmiş ve "güvenirlik" ve "geçerlik" testleri yapılmış iş tatmini ölçeğinin bulunduğu bir anket formu aracilığıyla 133 yiyecek içecek çalışanından veriler toplanmıştır.

Araştırmanın bağımsız değişkenini oluşturan "örgütsel psikolojik sermaye" ölçeği, orijinal biçimiyle "psikolojik dayanıklılık" (6 ifade), "öz-yeterlilik" (6 ifade), "iyimserlik" (6 ifade) ve "umut" (6 ifade) olmak üzere dört alt boyuttan oluşmakta; bağımlı değiş̧ken olan "iş tatmini" ise tek boyuttan (5 ifade) oluşmaktadır. Ölçekler için önce "açıklayıcı faktör analizi" ardından da "doğrulayıcı faktör analizi" yapılmıştır. Açılayıcı faktör analizinde, örgütsel psikolojik sermaye ölçeğinin orijinal 4 boyutlu formu, kimi ifadelerin farklı faktörlere yüklenmesi sebebiyle desteklenmemiştir. Analizin sonucunda, "örgütsel psikolojik sermaye” ölçeği, "psikolojik dayanıkl1l1k" ve "öz-yeterlilik” faktörleri birlikte tek alt boyut olarak, "iyimserlik" ve "umut" faktörleri de ikinci alt boyut olarak tespit edilmiş ve "doğrulayıcı faktör analizi" sonuçları ve ölçeğin "Cronbach Alfa" değerleri ölçeğin geçerliğini ve güvenirliğini ortaya koymuştur. Ayrıca "iş tatmini” ölçeği için de açıllayıcı ve doğrulayıc1 faktör analizleri ile güvenirlik analizleri yapılmış, faktör yükleri uygun olmayan ve ölçeğin yapısal geçerliliğini düşüren ifadeler ölçekten çıkarılarak sonuçlar ilgili tablolar ve grafiklerde sunulmuştur.

Açıklayıcı ve doğrulayıcı faktör analizleri sonucunda oluşan ölçeğin alt boyutlar bakımından değişmesi sebebiyle, ana hipotez aynı kalırken alt hipotezlerin sayısı ikiye düşürülmüştür. Ölçekleri son hali ve yeni hipotezler kullanılarak AMOS 23 programı kullanılarak bir yapısal eşitlik modellemesi yapılmıştır. 
Oluşturulan yol analizi sonucunda, örgütsel psikolojik sermaye ile iş tatmini arasında anlamı ve pozitif bir ilişki bulunduğu gözlenmiştir.

Alt boyutlar bakımında ele alındığında araştırmanın sonuçları aşağıdaki gibidir;

1. Psikolojik dayanıklılık ve öz-yeterlilik ile iş tatmini arasındaki yol katsayısı istatistiksel olarak anlamlı bulunmamış ve bu sebeple, " $\mathrm{H}_{1 \mathrm{a}}$ : Psikolojik dayanıkllık ve öz-yeterliliğin iş tatmini üzerinde pozitif bir etkisi vardır" alt hipotezi, reddedilmiştir.

2. "İyimserlik" ve "umut" ile "iş tatmini" arasındaki yol katsayısı istatistiksel olarak anlaml bulunmuştur ve " $\mathrm{H}_{1 \mathrm{~b}}$ : İyimserlik ve umut'un iş tatmini üzerinde pozitif bir etkisi vardır" alt hipotezi, kabul edilmiştir.

Yapılan literatür taramasında, araştırmanın bulguları ile benzer bulguların da bulunduğu tespit edilmiştir; Akçay (2012, s. 123), imalat sektörü çalışanlarında "psikolojik sermaye" ve alt boyutları ile "iş tatmini”" arasında anlamlı ve pozitif bir ilişki bulmuş; Çetin ve Basım (2011, s. 79), bankacilık sektöründe psikolojik dayanıklılık faktörü ile iş tatmini ilişkisini ortaya koymuş; Erkuş ve Fındıklı (2013, s. 302), umut, dayanıklılık alt boyutları ile iş tatmini arasında pozitif ilisski tespit etmiş; Ocak vd. (2016, s. 113) "iyimserlik" alt boyutunun "iş tatmini”" üzerinde pozitif etkilerinin bulunduğunu ifade etmiş; Biçkes vd. (2014, s. 97), psikolojik sermayenin tüm boyutları ile iş tatmini arasında anlamlı ve pozitif yönlü ilişki tespit etmiş; Çakmak ve Arabacı (2017, s. 890), "psikolojik sermaye"nin, "iş tatmini”" üzerinde olumlu etkiye sahip olduğunu ortaya koymuş; Çetin ve Varoğlu (2015, s. 105), psikolojik sermayenin iş tatminini artırdığını tespit etmiş; Luthans vd. (2008, s. 233), "psikolojik sermaye" ile "iş tatminil" arasındaki anlamlı bir ilişki olduğunu ortaya koymuş; Çetin (2011, s. 373) "iş tatmini"nin "örgütsel psikolojik sermaye"nin "umut" ve "iyimserlik" boyutları ile pozitif yönde ilişkili olduğunu tespit etmiş; Larson ve Luthans (2006, s. 75), yine" psikolojik sermaye" ile "iş tatmini” arasında anlamlı bir ilişki olduğunu ortaya koymuşlardır.

Her araştırmada olduğu gibi bu araştırmanın da birtakım sınırllıkları söz konusudur. Örneklemin yalnızca yiyecek-içecek sektörü çalışanlarından oluşması, araştırmanın önemli bir kısııını oluşturmaktadır. $\mathrm{Bu}$ sebeple araştırmanın sonuçları genellenemeyecektir. Ayrıca, araştırmanın Bişkek'te yapılması ve araştırmanın ölçeğinin farklı dillerden yapılan tercümelerden oluşmasının, farklı kültürlere sahip katılımcılarda farklı alg1lamalara sebep olabileceği de ayrı bir kısıt olarak dikkate alınmalıdır. Gelecek araştırmalarda farklı sektörler ve farklı kültürler üzerine yapılacak araştırmaları ile çalışmanın bulgularının doğrulanmasına gereksinim duyulmaktadır. Ayrıca gelecek araştırmacılara, örgütsel psikolojik sermaye ile iş tatmini dışında örgütsel performansı olumlu yönde etkileyen bağlılık, adanmışlık, vatandaşlık vb. değişkenlerle ilişkilerinin de araştırılması önerilmektedir.

\section{Etik Beyan}

"Örgütsel Psikolojik Sermaye ve Isş Tatmini İlişkisi: Bişseek'teki Yiyecek İgecek İsletmeleri Üzerine Bir Uygulama" başlıklı çalışmanın yazım sürecinde bilimsel, etik ve alıntı kurallarına uyulmuş; toplanan veriler üzerinde herhangi bir tahrifat yapılmamış ve bu çalışma herhangi başka bir akademik yayın ortamına değerlendirme için gönderilmemiş̧ir. Bu araştırmanın verileri 01.01.2020 tarihinden önce toplandığı için etik kurul kararı zorunluluğu taşımamaktadır.

\section{Kaynakça}

Akçay, V. H. (2012). Pozitif psikolojik sermayenin iş tatmini ile ilişkisi. Kabramanmaraş Sütçü İmam Üniversitesi İktisadi ve İdari Bilimler Fakültesi Dergisi, 2(1), 123-140.

Avey, J., Wernsing, T. S. ve Luthans, F. (2008). Can positive employees help positive organizational change? Impact of psychological capital and emotions on relevant attitudes and behaviors. The Journal of Applied Behavioral Science, 44(1), 48-70.

Avşaroğlu, S., Deniz, M. E. ve Kahraman, A. (2005). Teknik öğretmenlerde yaşam doyumu, iş doyumu ve mesleki tükenmişlik düzeylerinin incelenmesi. Selcuk Üniversitesi Sosyal Bilimler Enstitüiü Dergisi, 115-129.

Biçkes, D. M., Yılmaz, C., Demirtaş, Ö ve Uğur, A. (2014). Duygusal emek ile iş tatmini arasındaki ilişkide psikolojik sermayenin aracılık rolü: Bir alan çalışması. Eskişehir Osmangą̧ Üniversitesi İIBF Dergisi, 9(2), 97-121.

Çakmak, M. S. ve Arabacı, İ. B. (2017). Öğretmenlerin pozitif psikolojik sermaye algılarının iş doyumları ve örgütsel bağll1ıkları üzerindeki etkisi. Elektronik Sosyal Bilimler Dergisi, 16(62), 890-909.

Çetin, F. (2011). The effects of the organizational psychological capital on the attitudes of commitment and satisfaction: A public sample in Turkey. European Journal of Social Sciences, 21(3), 373-380.

Çetin, F. ve Basım, H. N. (2011). Psikolojik dayanıklılığın iş tatmini ve örgütsel bağlılık tutumlarındaki rolü. $\dot{I}_{s}$, Güc Endüstri İlişkileri ve Insan Kaynaklar Dergisi, 13(3), 79-94.

Çetin, F. ve Basım, H. N. (2012). Örgütsel psikolojik sermaye :Bir ölçek uyarlama çalışması. Amme İdaresi Drgisi, 45(1), 
121-137.

Çetin, F., Şeşen, H.ve Basım, H. N. (2013). Örgütsel psikolojik sermayenin tükenmişlik sürecine etkileri: Kamu sektöründe bir araştırma. Anadolu University Journal of Social Sciences, 13(3), 95-107.

Çetin, F. ve Varoğlu, A. K. (2015). Psikolojik sermaye , performans, ayrılma niyeti ve iş tatmini etkileşimi: Cinsiyetin düzenleyici rolü. Iss ve Insan Dergisi, 2(2), 105-113.

Clapp-Smith, R., Vogelgesang, G. R. ve Avey, J. B. (2009). Authentic leadership and positive psyhcological capital the mediating role of trust at the group level of analysis. Journal of Leadership Organizational Studies, 15(3), 227-240.

Eğinli, A. T. (2009). Çalışanlarda iş doyumu: Kamu ve özel sektör çalışanlarının iş doyumuna yönelik bir araştırma. Atatürk Üniversitesi İktisadi ve İdari Bilimler Dergisi, 23(3), 35-52.

Erkmen, T. ve Esen, E. (2013). Psikolojik sermaye ölçeğinin geçerlilik ve güvenilirlik çalışması. Öneri Dergisi, 10(39), 23-30.

Erkuş, A. ve Fındıklı, M. A. (2013). Psikolojik sermayenin iş tatmini, iş performansı ve işten ayrılma niyeti üzerindeki etkisine yönelik bir araştırma. İstanbul Üniversitesi İsletme Fakültesi Dergisi, 42(2), 302-318.

Gooty, J., Gavin, M., Johnson, P. D., Frazier, M. L. ve Snow, D. B. (2009). In the eyes of the beholder transformational leadership, positive capital and performance. Journal of Leadership Organizational Studies, 15(4), 353-367.

Hackman, J. R. ve Oldham, G. R. (1975). Development of the job diagnostic survey. Journal of Applied Psychology, 60(2), 159-170.

Karagöz, Y. (2016). Spss 23 ve Amos 23 uygulamal istatistiksel analizler. Nobel Akademik Yayıncilik.

Kaya, A., Balay, R. ve Demirci, Z. (2014). Orta öğretimde görev yapan öğretmenlerin psikolojik sermaye düzeylerinin incelenmesi (Şanlıurfa ili örneği). Elektronik Sosyal Bilimler Dergisi, 13(48), 47-68.

Kaya, İ. (2010). Otel işletmelerinde işgörenlerin iş tatminini etkileyen işi bırakma eğilimi. C..̈̈. Sosyal Bilimler Enstitüsü Dergisi, 19(2), 219-236.

Keleş, H. N. (2011). Pozitif psikolojik sermaye: Tanımı, bileşenleri ve örgüt yönetimine etkileri. Organiz̧asyon ve Yönetim Bilimleri Dergisi, 3(2), 343-350.

Kutanis, R. Ö. ve Oruç, E. (2014). Pozitif örgütsel davranış ve pozitif psikolojik sermaye üzerine kavramsal bir inceleme. The Journal of Happiness Well-Being, 2(2), 145-159.

Larson, M. ve Luthans, F. (2006). Potential added value of psychological capital in predicting work attitudes. Journal of Leadership and Organizational Studies, 13(2), 75-92.

Luthans, F., Avolio, B. J., Avey, J. B. ve Norman, S. M. (2007). Positive psychological capital: Measurement and relationship with performance and satisfaction. Personnel Psychology, 60, 541-572.

Luthans, F., Norman, S. M., Avolio, B. J. ve Avey, J. B. (2008). The mediating role of psychological capital in the supportive organizational climate employee performance relationship. Journal of Organizational Behavior, 29(2), 219-238.

Luthans, F., Youssef, C. M. ve Avolio, B. J. (2007). Psychological capital: Developing the buman competitive edge. Oxford University Press.

McMurray, A. ., Pirola-Merlo, A. ve Sarros, J. C. (2010). Leadership, climate, psychological capital , commitment , and wellbeing in a non-profit organization. Leadership Organization Development Journal, 31(5), 436-457.

Norman, S. M., Avey, J. B., Nimnicht, J. L. ve Pigeon, N. G. (2010). The interactive effects of psychological capital and organizational identity on employee organizational citizenship and deviance behaviors. Journal of Leadership Organizational Studies, 17(4), 380-391.

Ocak, M., Güler, M. ve Basım, H. N. (2016). Psikolojik sermayenin örgütsel bağlllık ve iş tatmini tutumları üzerine etkisi: Bosnalı öğretmenler üzerine bir araştırma. Çankır Karatekin Üniversitesi İktisadi ve İdari Bilimler Fakültesi Dergisi, 6(1), 113-130.

Oshagbemi, T. (2000). Satisfaction with coworkers' behaviour. Employee Relations, 22(1), 88-106.

Özer, P. S., Topaloğlu, T. ve Özmen, Ö. T. (2013). Destekleyici örgüt ikliminin, psikolojik sermaye ile iş doyumu ilişkisinde düzenleyici etkisi. Ege Academic Review, 13(4), 437-447.

Polatçı, S. (2014). Psikolojik sermayenin görev ve bağlamsal performans üzerindeki etkileri: Polis teşkilatında bir araştırma. Ege Academic Review, 14(1), 115-124.

Rego, A., Sousa, F. Marques, C. ve Cunha, M. P. e. (2012). Authentic leadership promoting employees' psychological capital and creativity. Journal of Business Research, 65(3), 429-437.

Şeşen, H. (2010). Öncülleri ve sonuclar ile örgüt içi girişimcilik: türk savunma sanayinde bir araştırma(Doktora Tezi). T.C. Kara Harp Okulu Savunma Bilimleri Enstitüsü Savunma Yönetimi Anabilim Dalı, Ankara.

Sevimli, F. ve İşcan, Ö. F. (2005). Bireysel ve iş ortamına ait etkenler açısından iş doyumu. Ege Akademik Bakı̧s Dergisi, 55-64.

Toor, S. R. ve Ofori, G. (2010). Positive psychological capital as a source of sustainable competitive advantage for organizations. Journal of Construction Engineering and Management, March, 341-353. 


\section{EXTENDED ABSTRACT}

Psychological capital, which emerges with the positive organizational behavior phenomenon, which reveals that people should focus on their strengths rather than weaknesses, is a fundamental phenomenon that managers who want to create a positive climate in their organizations have to invest in (Keleş, 2011, p.349).Psychological capital is defined as the positive psychological development state of the individual and is characterized by four components; (1) confidence and making the necessary effort to be successful in challenging tasks (self-efficacy); (2) positive attitude that it is successful now and will be successful in the future (optimism); (3) the determination to reach the basic goals and to be able to be directed to different goals that can change when necessary (hope) (4) to maintain the goal of success when surrounded by problems and difficulties (resiliency) (Luthans et al., 2007, p. 3).

Organizational psychological capital, which indicates the necessity of employees to focus on their strengths rather than their weaknesses, contributes to the formation of a positive climate in organizations by causing an increase in job satisfaction. In the research, the relationship between organizational psychological capital and job satisfaction was examined. The aim of the research is to enrich organizational psychological capital literature.

There are studies on the subject in the literature. Akçay (2012), Çetin and Basım (2011), Erkuş and Fındıklı (2013), Ocak et al. (2016), Biçkes et al. (2014), Çakmak and Arabacı (2017), Çetin and Varoğlu (2015), Luthans et al. (2008), Çetin (2011), Larson and Luthans (2006), etc. researchers examined the relationship between organizational psychological capital and job satisfaction and found significant relationships in their studies.

In this study, the employees of food and beverage companies operating in Bishkek, the capital of Kyrgyzstan, were selected as the sample. A questionnaire form was used in the research. The answers given to the questionnaire were taken through the scale of 5 Likert types (1: Strongly Disagree; 2: Disagree; 3: Neither Agree, Nor Disagree; 4: Agree; 5: Strongly Agree). The organizational psychological capital scale used in the research, Luthans et al. (2007) and adapted to Turkish by Çetin and Basım (2012) and tested for reliability and validity; Sample Questions; "I always see the good side of things about my job", "I am optimistic about what will happen to me in the future regarding my job", "If I find myself in a bottleneck while working, I can think of many ways to get out of it", "Right now, I consider myself very successful in my job", "I am confident in trying to find a solution to a long-term problem", "Since I had difficulties before, I can overcome difficult times in my job", "If I have to, I am self-sufficient at my job". The job satisfaction scale used in the study was developed by Hackman and Oldham (1975) and translated into Turkish by Şeşen (2010), and reliability and validity tests were performed, and the only scale is as follows; "My job is like a hobby for me", "I think I am happier at my job than many other people", "I enjoy my job very much", "In general my job satisfies me", "I think my current job is more interesting than any other job I can find".The data were collected from employees of food and beverage enterprises in Bishkek, using the convenience sampling method, one of the non-random sampling methods. Questionnaires were handed out to 150 managers and employees, and 145 of these were returned. 12 of the returned questionnaires were not included in the analysis due to their random filling and the high number of unmarked questions, and the total number of questionnaires used was 133.

Structural validity and reliability of the scales were tested by conducting both explanatory factor analysis and confirmatory factor analysis. As a result of the path analysis created by structural equation modeling, it has been determined that organizational psychological capital has a significant and positive effect on job satisfaction. Considering the sub-dimensions of organizational psychological capital; a) The sub-dimension of "psychological resilience and self-efficacy" does not have any significant effect on "job satisfaction", b) The sub-dimension of "optimism and hope" has a positive effect on "job satisfaction" was determined.

Organizational psychological capital and job satisfaction perceptions of the employees were measured with the study; The relationship between them is presented in detail as the findings of the study. According to this, the job satisfaction of the employees is high in the enterprises where the perception of organizational psychological capital is high. In today's world where competition is very high, businesses will be able to gain competitive advantage by increasing their employees' psychological capital and job satisfaction. 